\title{
Scientific Basics of Forming Human Quality and Perfection to Ensure Holistic Sustained Development
}

By

\section{${ }^{1}$ Nickolay Suvorov and ${ }^{2}$ Iryna Suvorova}

\begin{abstract}
The general substance underlying the existence and development of the Universe and Man is energy. Energy is the unique and universal nature of all being. Everything is reduced to the amount and quality of energy.

We were the first in the world to scientifically substantiate harmony as the universal criterion of the quality of energy of inner and outer interaction, optimality, perfection of energy-information images and systems of diverse nature.

The harmony help solve the problem of forming high quality and perfection of human personality.

Harmony is the key technology of creation, which God introduced when creating the Universe.

The principles of harmony and holism are the basic components of Cosmo theory, the theory of development of the Universe and Man.

In concentrated form, the theoretical studies dedicated to harmony and forming a new and perfect human being are presented in the book by NIKOLAI SUVOROV: " $\alpha \rho \imath \sigma \tau O \varsigma \alpha v \theta \rho \omega \pi o \varsigma$ - Perfect Man", International Publishers ERA, 2014, 300 pp. Embracing harmony creates conditions for sustained development-evolution of any human being, nation and civilisation as a whole.

We believe that in the EU countries it would be practical to set up R\&D and perfection training centres for studying and practically applying harmony.
\end{abstract}

Key words: Harmony, quality, perfection.

\section{Introduction}

The strategy of a holistic and sustained development depends on and is conditioned by a scientifically substantiated theory of development of humans and humanity. The theory of development or the concepts of the theory of development can be substantiated without knowledge of their essence and principles of developmentevolution of humans and society that form policy, the economy, the state and all its 
superstructures. Hence, the paramount thing is the scientific substantiation of the strategy of development-evolution of humans, thus forming a prime and perfect individual and a collective of individuals - groups, collectives of people, and as a whole, of society and the nation. Hence, in the first place, in the context of science, it is essential to substantiate the lines of development of Homo sapiens; develop methods and means of forming new humans, viz. humans with new qualities, principles, laws, and rules of a whole lifestyle - the humans of the future.

The call for quality and quality changes is the response to the challenges of time and the New Epoch. Qualitative changes presuppose creation and formation of everything new and advanced; the aspiration to progress and an integral and systemic optimisation, to a new stage of evolution of humans, to harmony and perfection, to acme (Greek $\eta \alpha \kappa \mu \eta)$ - the summit, the supreme point - and to opulence, prosperity, and welfare. In established modern terminology, fundamental changes are called innovative ones. In spite of the relatively high level of development of science, presently there is no theoretically substantiated path of human development-evolution. Humans are actually 'developing' according to the principle stated in Russian folk tales: Go I Know Not Whither!

The absence of an idea of national development in both the 'new' countries of the CIS of the former USSR and the 'old' countries of Europe and America prove the correctness of the above statement.

Free will and freedom of choice are the dominant ideas of a life philosophy. With this in view, the duty and responsibilities of a human became secondary with regard to one's rights. Moreover, it is worth mentioning that, for a long time, a primitive philosophical dogma was formed and instilled in the minds of the majority of people, viz. that matter, material welfare and material wellbeing are primary, and that consciousness (energy of mind) is secondary. Consciousness and supreme entities turned out to be secondary, their role being reduced to servicing lower entities, in particular, the insatiable physical body. Eventually, a vague mind-set had begot a stable image of a human being as consumer.

Absolutisation of matter and the physical body led to incomprehension of the complex composite and, at the same time, holistic energy-informational essence of the human being. The distorted interpretation of human nature precluded establishing the essence of the quality and criteria of perfection of the human personality, and determining the direction of development-evolution of Homo sapiens.

Without belief, lofty ideals and anchorages, without honour and conscience, and morality and ethics, and without an aspiration to the summit and perfection, Homo sapiens has degenerated and deteriorated.

The Lord said, 'To remove the self-destruction program, it is essential, above all things, to change the human worldview.' [1]

The human being is meant to be Homo sapiens irrespective of his socioeconomic, ideological, religious and national environment. All people taken together, jointly, including the faithful, over a long period have formed a self-destruction program. 


\section{On the necessity of developing morality and ethics}

By playing down the role and significance of the principal philosophical issue till present, humanity failed to develop the fundamentals of a proper worldview - a system of moral and ethical norms, and principles of human development-evolution based on the Great Cosmic Law, Law of Development, God's Law, and the Law of Harmony, which would allow substantiating the methods of solving the problem of forming a prime and perfect human personality.

Unfortunately, reference and philosophy literature gives no clear definition of the notions of morality and ethics. For example, in encyclopaedic dictionary [2], compiled under the supervision of a big group of prominent scientists, the following definitions are used: ethics - see morality; morality - see ethics. Such definitions can be used solely as a grotesque. Every reader can assure oneself in the simplified interpretation of ethics and morality.

If the content and form of a word have not been formulated, then such a word is insentient and empty. Hence, even theory has not offered in full the norms of moral and ethical principles of life, which would be compulsory for each and all individuals living in one environment, and one energy-informational field and space.

Without a comprehensive knowledge of morality and ethics, a discussion on the content of a proper worldview would be impossible. Without assimilating a system of moral and ethical categories of life and being, individuals and society become immoral and unethical.

The universal substance underlying the existence and development of the Universe and Humans is energy: the fine energy of the spirit, reason, senses, emotions, desires, as well as the dense energy of matter. Energy is the unique and universal essence of all Being.

From the viewpoint of the advanced achievements of many young sciences of the $20^{\text {th }}$ century, a society and a nation can be considered complex energy-informational (bio energy-informational) images and systems. The energy-informational approach makes it possible for researchers to arm themselves with analysis and synthesis methods, which have gained a foothold in physico-mathematical and engineering sciences, to form new anthropological energy-informational images of humans and collectives of people.

Energy is an entity that unites EVERYTHING, seemingly not lending itself to unification, and it can solve things, which seemed unsolvable. EVERYTHING is reduced to the quantity and quality of energy, and the quality of energy of interaction.

The quality of energy of interaction of people is defined by ethics and, as whole, by the worldview. Absence of canons, laws, rules of ethics, and a proper worldview give rise to full liberty of morals, disturbed moderation in everything and, as a consequence, a degraded quality of the human personality, and a bad quality of energy of interaction between people.

We were the first to scientifically substantiate and prove that the universal criterion of the quality of energy of inner and external interaction, and optimality and perfection of energy-informational images and systems of different nature is harmony. 


\section{Mathematical interpretation of harmony}

The Supreme Spiritual Hierarchs stress the necessity and expediency of cognising harmony.

THE LOGOS OF LORD THE GOD: 'All development proceeds to create maximal harmony. This is what one must aspire to.' [1]

THE LOGOS OF JESUS CHRIST: 'It is harmony to what a human must aspire to; however, the search for harmony is a challenging task and solving it is the goal of everything manifested and existing.' [1]

Presently, we have developed a philosophical and mathematical interpretation of harmony, and have defined its quantitative measure. Practical computations of harmony for simple and complex technical energy-informational images and systems [3-8], and for live organisms [9] have been done.

Comprehensive research into harmony has been done in authors' papers [4 - 7].

This paper expounds certain fundamental concepts exposing the essence of harmony.

A scientific substantiation of harmony can introduce revolutionary change to many areas of vital activities of an individual person and of all people, but mainly it can help solve the problem of forming a prime and perfect human personality.

The word correlation and its derivatives autocorrelation and mutual correlation correspond to the utmost to the sense of the word harmony.

Autocorrelation - concordance, coincidence, similarity, correspondence, affinity, coalescence, and unity with a reference or ideal image.

Mutual correlation - balance, equilibrium, steadiness of opposite categories (Yang, Ying), opposing energies ('+', '-').

Auto and mutual correlation have a mathematical form of presentation; hence, the harmony of energy-informational images can also be expressed mathematically. In mathematical terms, the harmony of energy-informational images of different nature is described by the condition of orthogonality in the form of two functionals:

the coefficient of autocorrelation of reference or ideal ones with real energyinformational images $-\rho$;

the coefficient of mutual correlation between energy-informational images $-r$.

Thereat, autocorrelation coefficient $\rho$ defines inner harmony, and mutual correlation coefficient $r$ defines external harmony.

The coefficients of auto and mutual correlation are determined by expressions

$$
\frac{1}{E_{0}} \int_{\{t\}} S_{i}(t, C) S_{s j}(t, C) d t=\left\{\begin{array}{l}
\rho, i=j, \\
r, i \neq j,
\end{array} \quad i, j=\overline{1, M} .\right.
$$

The full energy $E$ of inner and external interaction of energy-informational images has the form

$$
E=\int_{\{t\}} S_{i}(t, C) S_{s j}(t, C) d t=\left\{\begin{array}{l}
E_{0} \rho, i=j, \\
E_{0} r, i \neq j,
\end{array} \quad i, j=\overline{1, M} .\right.
$$


Here, $\left\{S_{i}(t, C)\right\}_{i=1}^{M}$ is the set of real energy-informational images, $M$ is set dimensionality, $\left\{S_{s j}(t, C)\right\}_{i=1}^{M}$ is set of reference energy-informational images, $C$ is energy parameter, a multidimensional value (vector), $E_{0}=\int_{\{t\}} S^{2}(t, C) d t=\int_{\{t\}} S_{s}^{2}(t, C) d t$ is own energy of images, $\{t\}$ is observation time interval. For orthogonal energyinformational images, the condition $\rho=1, r=0$ holds.

\section{The harmony-ethics and harmony-morality Logos}

The necessity to develop lofty moral and ethical norms and principles of interaction of people requires the introduction of a new Logos, viz. harmony-ethics and harmony-morality. Logos is a word linked to reason into a unique and inseparable whole. Harmony-ethics is an affirmation of that the fundamental principle of ethics is harmony, or more specifically, inner harmony. The ethics of an individual is an evaluation of the quality of his/her inner content, character, disposition, habits, and worldview. Ethics characterises the inner harmony of a person by comparison or the mathematical operation of convolution of the person's energy-informational image with a certain model or ideal image. The Supreme Ideal Energy-Informational Image for a human being is God. God is the Energy-Informational Field with a positive creative energy, a Creator of 'Luminous Forces' of the World.

Sanskrit helps establish the philosophical interpretation of the category of ethics. In Sanskrit, yoga means 'relation and unity'. Yoga is a means of uniting a person with God, achieving the supreme level of inner harmony.

In mathematical terms, the supreme level of harmony-ethics corresponds to autocorrelation coefficient $\rho=1$. Equality $\rho=1$ means that a person has formed a prime energy of inner interaction with the Ideal Energy-Informational Image.

An approach to the potential level of ethics is a manifestation of the best concordance of a person with God, an attainment of harmony-love with HIM, and hence, of love for oneself and other human beings.

A high level of inner harmony, a better character, disposition, exemplary behaviour, noble skills and habits, and as a whole, a proper worldview favours the formation of a lofty positive potential and energy of love in a person.

Love is the supreme ethical category of harmony-ethics. Love is the supreme positive ethical trait. Love is the fundamental component of a proper worldview.

Knowledge of the inter-relation of harmony-ethics and harmony-love is required for both forming an education philosophy and a philosophy of treatment-healing. With the help of love, and realising the principle 'love thyself', a person can heal oneself. With the help of love, other people can be healed, including, demonical beings.

Hence, ethics has a dramatic impact on the energy-informational potential and, consequently, on the quality of a human personality.

Harmony-ethics characterises a person's inner perfection; the level of development of the quality of the astral, mental, and spiritual body, and overall own development to 
increase harmony. The process of maximising inner harmony is the ethical perfection of the human personality. Thus, inner harmony of the human personality is the basis of harmony-ethics.

The external harmony of the human personality is the foundation of harmony-morality, moral principles, canons, laws, rules, codes, high norms of interaction and association of people during their joint vital activities.

If ethics defines the image and personal profile directly, morality characterises a person's social image, and one's ability to live among other people, and be helpful in a team and collective.

Taken together, ethics and morality define the holistic image of a human being, exposing one's individual and social fitness.

A high level of an individual's personal harmony is an inseparable union of inner and external harmony-ethics and harmony-morality.

Both in form and essence, inner and external harmony, and hence, harmony-ethics and harmony-morality differ significantly. Inner harmony is not external by definition. Similarly, ethics is not morality. These notions differ in essence and form.

In terms of mathematics, inner harmony and harmony-ethics are determined by the autocorrelation coefficient, whereas external harmony and harmony-morality are determined by the mutual correlation coefficient.

Harmony-ethics characterises the prime inner traits of human personality. The quality criterion is the level of harmony of a person with God, or the degree of affinity (correspondence) of a person's image to the Image of God.

Harmony-morality characterises the quality of interaction of people among themselves and the environment. The quality criterion is the Law of Conservation of Harmony, the CREATOR'S LAW [1].

The law of unity, the harmony of opposites, or the Law of Conservation of Harmony is formulated as follows: the total quantity of energy with the signs plus ('+') and minus (' - ') should be balanced ('+' $+{ }^{\prime}-{ }^{\prime}=0$ ), with the mutual correlation coefficient $r=0$ [4].

The CREATOR'S LAW defines the content of external harmony. The ideal external harmony is peace (calm) when a balance, equilibrium of opposing energies and opposing categories Yang-Ying is attained.

Moral improvement of a human personality is the process of maximising one's inner harmony.

THE LOGOS OF LORD THE GOD: 'An optimal variant of existence of the World and Antiworld is the 'golden mean' between energies of different polarities. Harmony should be in the first place, i.e. the number of pluses and minuses should be equal. This should be the goal. One should always strive to equilibrium of opposing principles, and this should be the optimal variant. Contradictions per se are necessary at all times because without them nothing can exist, there would be no change, and hence, life would be impossible. Certainly, the greater the contradictions the more speedy are the paces of transformation and change.' [1]

The commandment 'Do no harm' is the origin and foundation of proper moral principles of interaction of people. Medics have proven the vitality of this commandment by proclaiming and affirming the Hippocratic Oath. 
THE LOGOS OF LORD THE GOD: 'A person should act so as not to harm another person.' [1]

The following Greek words illustrate well the meaning of the term 'morality': o $\sigma \nu \mu \beta \imath \beta \alpha \sigma \mu \sigma_{\varsigma}$ (simvivazmos):

- concord, peace;

- conciliation, concordance;

- concession, compromise, conciliation (politics).

$\eta \sigma v \mu \beta \imath \beta \alpha \sigma \eta$ (simvivasi): concord, peace.

$\sigma v \mu \beta \imath \beta \alpha \zeta \omega$ (simvivazo): coordinate, settle, reconcile, bring into accord. $\sigma \nu \mu \beta \imath \beta \alpha \zeta o \mu \alpha \iota$ (simvivazome):

- be reconciled, bring to agreement, to compromise;

- to coincide, to be compatible.

Close in form to the above Greek words is the word $\eta \sigma v \mu \beta \imath \alpha$ (simvia): wife, spouse - creator and keeper of the family hearth, calm, peace.

Easy disposition, tolerance, and humanity are the most important virtues of morality.

The Greek language has a wonderful word $\eta \varepsilon \gamma \kappa \rho \alpha \tau \varepsilon i \alpha$ (engkratia) - abstention, moderation, restraint, composure, and tenacity. Engkratia means upbringing and selfeducation of appropriate inner qualities and traits, as well as the epoch of prolonged transition from an immoral Homo sapiens to the initial stage of development of a perfect human being, society and state.

The Latin word tolerantia is close in meaning to the Greek word engkratia. Tolerance (tolerance to other opinions, beliefs, and behaviour) is an important human trait for establishing harmonious principles of interaction between people.

Peace is the highest ethical category of harmony-morality. Peace and love are two fundamental components of a proper worldview.

In mathematical terms, the operation of optimisation of technical and improvement of anthropological energy-informational images and systems according to the maximum harmony criterion is reduced to solving the minimax problem: maximising the functional of the autocorrelation coefficient $(\rho \rightarrow 1)$ and minimising the functional of the mutual correlation coefficient $(r \rightarrow 0)$ to provide maximum quality and quantity of interaction energy.

Harmony unites in a whole such categories as high quality, optimality, and perfection. All things supreme and best are reduced to high-quality harmonised energy.

\section{Energy and ethics}

The qualitative and quantitative indicators of the energy of interaction of people depend on their own energy and laws, and rules of ethics, in particular, harmony-ethics and harmony-morality. Mathematically, this statement is determined by the expression [4] $E=m E_{0}(\rho-r)$, where $E$ is energy of full (inner and external) interaction; $m$ is number of interacting individuals; $E_{0}$ is the own energy of individuals; $\rho$ is 
autocorrelation coefficient determining inner harmony and harmony-ethics; $r$ is mutual correlation coefficient determining external harmony and harmony-morality.

The energy of interaction includes the categories of quality and quantity. The quality of the energy of interaction is determined by inner and external harmony - the maximum of the autocorrelation coefficient $\rho$ and the minimum of the mutual correlation coefficient $r$.

The maximum quantity of energy of interaction is determined by own energy $E_{0}$. The highest quantitative value of energy of interaction $E=E_{0}$ is provided by achieving the highest indicator of the quality of energy of images, and the highest indicator of their inner and external harmony: $\rho \rightarrow 1, r \rightarrow 0,(\rho-r) \rightarrow 1$, and hence, the supreme quality of images as a whole.

Orthogonal simple and complex energy-informational images possess supreme quality. Orthogonal images are potentially ideal harmonised energy-informational ones. They provide the highest indicators of inner and external harmony, and thereupon, the highest indicators of the quality and quantity of interaction energy.

Orthogonality of anthropological energy-informational images is provided by maximising harmony-ethics $(\rho \rightarrow 1)$ and harmony-morality $(r \rightarrow 0)$. Indicator $(\rho-r)$ of joint harmony-ethics and harmony-morality allows in mathematical form to determine the essence of good and evil, evolution-involution, and creation-destruction.

The given expression for the energy of interaction in mathematical form reflects the union, or in better terms, the merging and harmony of science and religion into one whole. Energy is the realm of study for science. Ethics should be formed by religion. Jointly, science and religion should help people form the requisite quality and quantity of interaction energy.

The ethical categories 'peace $(r=0)$ and love $(\rho=1)$ ' form the highest quality and quantity of energy of interaction of people $E=m E_{0}(\rho-r)=m E_{0}$, ensuring there at the focusing of individuals energy to a unique whole. Peace and love ensure formation of harmonised energy.

However, if the ethics and morality indicators are low $(\rho \rightarrow 0, r \rightarrow 1)$, then, at any arbitrary large values of $m$ and $E_{0}$, the energy potential of a collective of individuals will be low or even negative, and this can result in its total self-destruction.

Any matter, including economics, cannot develop effectively without high-quality interaction energy and a prime human being. It is formed with the help of harmonyethics, harmony-morality, and a proper worldview. Harmonised energy, the dense energy of the physical body and the fine energy of human hearts, minds and souls is primary. Matter, as a result, is secondary.

A not idle inquiry is what kind of personal harmony should be established first - inner or external?

THE LOGOS OF LORD THE GOD: 'The wisest people are those who understand that, to build one's harmony, it is necessary first to build the harmony of one's environment. Otherwise, personal (inner) harmony will be unstable and temporal. It will be destructed due to energy links with an inharmonious environment.' [1] 
Hence, external harmony, forming morality, moral principles, mutual communication principles, rules, laws, and codes of co-existence are primary.

However, external harmony is linked to inner harmony, and morality cannot exist without ethics. To transform oneself, intensive inner efforts are needed. It is known that the 'Kingdom of Truth' is inside us. The main source of knowledge is inside us. Open this source in yourself and all external circumstances will manifest themselves immediately according to the inner transformation. Inner transformation is a radical change in thoughts, feelings, desires, emotions, worldview, behaviour, character, and a continual process of drawing nearer to a model, an ideal, and an Image of Lord the God.

\section{Worldview and Cosmotheory}

A human being can transform oneself to being a slave of desires and being preoccupied only with the matters of one's lower bodies. However, a human being has everything to be ones' own master, to know how to control both the lower and higher bodies, and to control the fine energy of creation, and the spiritual and psychic energy. It is necessary to learn how to subordinate malign desires to more lofty and spiritual ones. All people have demonical elements to a different extent. Each person is given the chance of aspiring to harmony, perfection and transformation. Even overt demonical beings have chances to transform; however, their transformation requires prime harmony energy. Love contains such prime harmony energy.

The scientific results obtained are used, primarily, as a theoretical basis for formation bringing up and educating a perfect human being, a human of the future. The possibility of formation of a perfect human personality is real due to the mathematical and philosophical substantiation of the perfection criterion. The general definition of a perfect human being, as a holistic complex energy-informational entity, is as follows.

According to the criterion of maximum harmony, a perfect human being is one who professes harmony and is focused on attaining ideal (full) harmony.

A version of the future exists, in which humanity will achieve the level of consciousness of a perfect human being - the consciousness of Christ.

In Greek, a perfect human being is $\alpha \rho \imath \sigma \tau o \varsigma \alpha \nu \theta \rho \omega \pi o \varsigma$ (aristos antropos). Having formed an $\alpha \rho \imath \sigma \tau \sigma \varsigma \alpha v \theta \rho \omega \pi \sigma \varsigma$, one can be assured that, in the process of evolution, people will create a perfect state $\alpha \rho \imath \sigma \tau o \varsigma$ $\kappa \rho \alpha \tau O \varsigma$ (aristos kratos) and a perfect society $\alpha \rho \imath \sigma \tau o \kappa \rho \alpha \tau \imath \alpha$ (aristokratia).

From the energy-informational viewpoint, the main mission of humans in Cosmos is generating high-quality harmonised energy. All human activity should be subordinated to solving this strategic problem. Solving the problem of creating prime energy demands the metamorphosis of Homo sapiens by changing the quality of human personality and transition to aristos antropos.

The saying is that there are no limits to perfection. This holds here because there are no limits to development of belief, spirituality, and harmony in humans.

The Lord said, 'To ascend, a person, above all things, has to achieve a high degree of harmony.' [1] 
Here, Jesus Christ explains, 'True harmony can exist only in the ABSOLUTE, but no one, even those whom you consider to be your gods, are not a model of complete harmony. These are only steps of approaching it, and one can ascend this ladder to infinity.' [1]

Developing the fundamentals of the theory of harmony allows formulating the essence of a proper worldview. The essential components of a proper worldview are the categories of belief, spirituality, and harmony. Hence, an evaluation of the quality and perfection of the human personality can be adjusted and developed based on cognising the essence of a worldview.

The Greek language provides a more keen insight into the content of the concept of worldview, which is universally vital for human beings. In Greek, worldview is

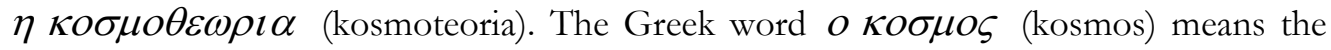
following: Cosmos, Universe, world, society, nation, and people. Hence, Cosmo theory is the theory of development of people and the Universe [4]. People (cosmos) and the Universe (Cosmos) have the same name, and this is evidence of the wisdom of ancient Greeks. However, this is a theory intended not for today, but rather for the future. Presently, one can speak only about its concepts. Hence, the process of cognising the essence of the human personality and its major categories - quality and perfection - is infinite.

The research conducted allows formulating the strategy of a holistic and sustained development-evolution of a human being and humanity in the New Era - the 21 st century, the new millennium, the Aquarius epoch.

The strategy of development-evolution of a human being and humanity consists in formation - upbringing and educating a perfect human professing a proper worldview, with the basic components of belief, spirituality, harmony-ethics, harmony-morality, harmony-peace, harmony-love, mutual understanding, patience, tolerance, personal and collective harmony, full harmony, and Christ's ethics.

A perfect human being can unite the ideas of national development of different countries, religions and nations into a unique whole to create an ERA of PEACE and LOVE. Hail to a perfect human!

\section{Conclusions}

The ecological, socio-economic, cultural, and as a whole, systemic sustainable development of a nation and civilisation is inseparably associated with formation of a prime and perfect human personality.

Such a personality is maintained by a proper worldview, the basic components of which are belief, spirituality and harmony.

The basic components of a worldview are capable of ensuring prime energy of interaction and unification of the human being with the CREATOR, and with the GOD. We are willing, jointly with interested persons and organisations, to continue research in substantiating the strategy of integral and sustained development of Europe. We believe that in the EU countries, Ukraine, Russia and other countries it is necessary to establish perfection $\mathrm{R} \& \mathrm{D}$ and training centres to study harmony and apply it in practice. 


\section{References:}

Садецкий Т.А., Садецкий В.А. Большой Огонь Галактики И Мы. - М.: Жоалино, Белые альвы, 1997. $-656 \mathrm{c}$.

Советский энциклопедический словарь. - М.: Сов. Энциклопедия, 1985. - 1600с.

Суворов Н.П. Системы каналообразования и проводной связи. Учебник, Издательство МО СССР, 1991. $-412 \mathrm{c}$.

Суворов Н.П. А

Суворов Н. П., Суворова И.Г. Введение в космотеорию Части I - VII. - Харьков: Издательство Шуст А.И., 2001, 2002, 2003. - 172c.

Суворов Н.П. Гармонический анализ как способ познания человека //Медична гіАрологія та реабікітація. - 2003. - 1, №2 -С.100 -107; - 2004. - 2, №1 -C.91-102; - 2004. - 2, №2 -С.70 -79; - 2008. - 6, №4 -C.109 - 118; - 2009. - 7, №1 -C.103 - 109; - 2009. - 7, №4 -C.111 - 124; - 2010. - 8, №1 -С.24 - 30; - 2010. - 8, №4 -С.73 - 78.

Суворов Н.П., Суворова И.Г. Концепции космотеории // Медична гілрологія та реабілітація. - 2004. - 2, №3 -C.58 -73; - 2004. - 2, №4 -C.84 - 95; - 2005. - 3, №1 -С.81 - 96; - 2005. - 3, №3 -C.63 - 87; - 2007. - 5, №1 -C.41 - 52; - 2008. - 6, №2 -C.86 - 94; - 2008. - 6, №3 -C.154 - 162; - 2012. - 10. №3 -C. 93 - 108; - 2012. -10. №4-C. 61 - 90; - 2013. - 11. №2 - C. $46-50$.

Suvorova Iryna. Developing the theoretical foundations of system optimization for addressing effectively energy security issues to ensure the strategy of Europe's integrated and sustainable development. Paper presented at the Special Forum \& Exhibition on BEST OF EAST - FOR EASTERN PARTNERSHIP. November 28-30, 2011 WARSAW, Poland. $5^{\text {th }}$ International FORUM Science \& Technology Days Poland-East.

Попович I. $\Lambda$. Стреслімітуючий адаптогенний механізм біологічної та мікувальної активності води Нафтуся. Монографія. - К.: Видавничий Аім "Комп’ютерпрес", 2011. - 300с.

\section{Translating References into English:}

Sadetsky TA, VA Sadetsky Great Fire Galaxy And We. - M.: Zhoalino, White Alva, 1997. - 656p.

Soviet Encyclopedic Dictionary. - Moscow: Sov. Encyclopedia, 1985. - 1600p.

Suvorov N.P. Channeling system and wired communications. Textbook Publisher USSR Ministry of Defense, 1991. - 412p.

Suvorov N.P. A $\rho \imath \sigma \tau O \zeta \alpha v \theta \rho \omega \pi O \zeta$ - The perfect man. - M.: E.RA 2014. - 304p.

Suvorov N.P., Suvorova I.G. Introduction to Cosmotheory. Part I - VII. - Kharkov: Publishing Shust A.I. , 2001, 2002, 2003. - 172p.

Suvorov N.P. Harmonic analysis as a way of human cognition// Medical Hydrology and Rehabilitation. 2003. - 1, №2 -C.100 -107; - 2004. - 2, №1 -C.91-102; - 2004. - 2, №2 -C.70 -79; - 2008. 6, №4 -C.109 - 118; - 2009. - 7, №1 -C.103 - 109; - 2009. - 7, №4 -C.111 - 124; - 2010. - 8, №1 -C.24 - 30; - 2010. - 8, №4 -C.73 - 78 .

Suvorov N.P., Suvorova I.G. The Cosmotheory conceptions//Medical Hydrology and Rehabilitation. . 2004. - 2, №3 -C.58 -73; - 2004. - 2, №4 -C.84 - 95; - 2005. - 3, №1 -C.81 - 96; - 2005. - 3, №3 -C.63 - 87; - 2007. - 5, №1 -C.41 - 52; - 2008. - 6, №2 -C.86 - 94; - 2008. - 6, №3 -C.154 - 162; - 2012. - 10. №3 -C. 93 - 108; - 2012. -10. №4 -C. 61 - 90; - 2013. - 11. №2 - C. $46-50$.

Suvorova Iryna. Developing the theoretical foundations of system optimization for addressing effectively energy security issues to ensure the strategy of Europe's integrated and sustainable development. Paper presented at the Special Forum \& Exhibition on BEST OF EAST - FOR EASTERN PARTNERSHIP. November 28-30, 2011 WARSAW, Poland. $5^{\text {th }}$ International FORUM Science \& Technology Days Poland-East. 
Popovich I.L. Streslimituyuchyy adaptogenic mechanisms of biological and therapeutic activity of water NAFTUSA. Monograph. - K.: Publishing House "Computerpress", 2011. - 300p. 